\title{
Clinical responce to cardiac resynchronisation therapy
}

\author{
Željko Delić ${ }^{1}$, Slavica Ćirković ${ }^{2}$ \\ ${ }^{1}$ General hospital Vrbas, ${ }^{2}$ General hospital Požarevac
}

Abstract

Introduction: Cardiac resynhronisation therapy (CRT) improves symptoms of systolic heart failure (HF), functional ability and quality of life, reduces mortality and increases life expectancy.

Objective: The aim of this study was to present results in the treatment of systolic HF using CRT, at least 12 months after the implantation.

Methods: The analysis was retrospective and presents the effects of CRT therapy in 105 patients, mean age $63 \pm 8.7$, with QRS width $159.1 \pm 23.1 \mathrm{msec}$ in NYHA HF II, III and ambulatory class IV, with optimal medical therapy. Among the patients, 36 of them had HF as a result of ischemic cardiomyopathy (ICM) - previous myocardial infarction had 25 patients $(23.8 \%)$, and 69 of them had hearth failure of non-ischemic origin.

Results: A year after CRT stimulation, there was a statistically significant reduction of the QRS width, reduction in NYHA HF class, extension of the distance by 6MHWT, improvement of LVEF, and number of hospitalizations after procedure. In this study, $60 \%$ of patients were responders to CRT, $15 \%$ belong to the group of super responders, and $25 \%$ in this analysis were non- responders to CRT.

Conclusion: In our population, CRT treatment reduced mortality, clinical condition improved, as well as the quality of life in patients with symptomatic systolic HF.

Key words heart failure, cardiac resyinchronization therapy

The first and fundamental task of the cardiologist is to get acquainted with the diagnosis and treatment of heart failure.

Sir Thomas Lewis, 1913.

\section{Introduction}

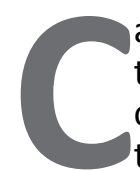

ardiac transplantation is the "gold standard" for treating patients with terminal cardiac insufficiency, with significant improvement in survival, tolerance of physical effort and quality of life. The disadvantages of method are small donors numbers, side effects of immunosuppressive therapy (infection), arterial hypertension, renal insufficiency, malignancies and coronary arterial vasculopathy. ${ }^{1}$ The disadvantages of transplantation, especially the small number of donors, led to the advancement of the device for mechanical circulatory support, as well as the resynchronization pacemakers, which are now considered as reliable alternative in the treatment of these patients in terms of "Bridging" the period to the heart transplantation. In addition, today it is increasingly used as treatment modality for systolic heart failure (HF) with wide QRS complexes.

Resynchronization therapy of heart failure (CRT), as established as a form of non-pharmacological approach for the treatment of resistant to medications HF with proven asynchrony, with improvement in symptoms, reduced mortality, longer duration, and better quality of life. ${ }^{2}$ The CRT challenge is still a high rate of patients with an inadequate response to the CRT, as well as the choice of optimum position and number of implanted electrodes on the left ventricle.

The aim of the analysis was to present the results for the treatment of systolic HF, using a CRT, by evaluating clinical response a clinical response to this therapy at least 12 months after implantation.

\section{Methods}

By random selection from the computer database of the Pacemaker Center, Clinical center Serbia in Belgrade, 105 patients were included: 77 men and 28 women. The average age of the patient was $63 \pm 8.7$ years. The youngest respondent had 32 and the oldest 81 years, all of them had systolic left ventricular dysfunction with an average left ventricular ejection fraction (EFLV) before the intervention $26.0 \pm 5.9 \%$, with the left bundle branche block (LBBB) in 103, and the right bundle branch block (RBBB) in 2 subjects, a QRS complex with an average width of $159.1 \pm 23.1 \mathrm{msec}$, belonged to the New York Heart Association (NYHA) HF functional class II, III and ambulatory HF class IV with one subject, who were on 


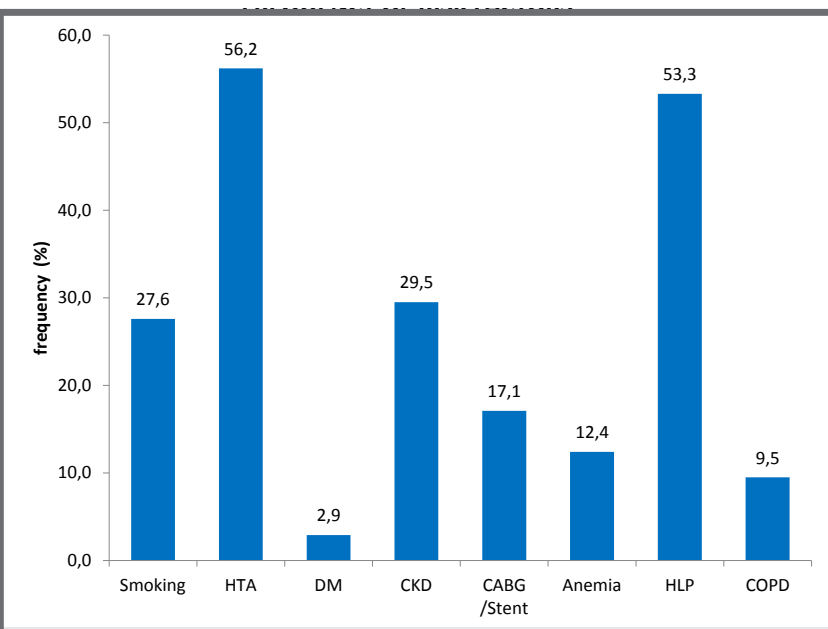

Figure 1. Frequency of risk factors

optimal medication therapy before implantation of CRT. 36 of them had HF as a result of ischemic cardiomyopathy- previous myocardial infarction had 25 patients $(23.8 \%)$, and 69 of them had cardiac weakness of nonischemic genesis. Of all respondents involved in the study, smokers were 29 (27.6\%), HTA had 59 (56.2\%) DM had 3 $(2.9 \%)$ subjects. CKD had 31 (29.5\%) subjects,.CABG / or STENT had 18 (17.1\%) subjects. Anemia has been reporting among 13 (12.4\%) subjects. HLP had 56 (53.3\%) subjects,.COPD were noticed among 10 (9.5\%) respondents.

As parameters of positive clinical response to CRT, following parameters were included:

- Reduction of the functional NYHA class of HF by 1 or more

- Increase the distance traveled to 6MHWT by more than $20 \%$

- Reducing the use of diuretics

- Reduction of hospitalization and death in the observed period)

- Improvement of LVEF > 5\%

In all patients, a 12-channel ECG, a routine laboratory treatment, and a 6MHWT /length walk along a flat corridor for a six-minute time period/, as well as an ECHO cardiographic examination, were performed prior to CRT implantation. Retrospective analysis was achieved by insight in to disease history, control chart and ECHO database, and data obtained in telephone contact with respondents resulted in the following results:

\section{Results}

In this analysis, a statistically significant improvement in the clinical and echo- cardiographic parameters after the implementation of CRT was observed.

One year after a CRT stimulation:

- The duration of the QRS complex is reduced.

QRS widh was reduced by $15.5 \mathrm{msec}$ (159.1 VS 143.6 $\pm 20.6 \mathrm{msec})$ - statistically significant difference $(\mathrm{t}=$ 7.461; $p$ <0.001). The most significant reduction in the duration of the QRS complex was $45 \mathrm{msec}$. In one respondent whose duration of QRS complex before stimulation was $110 \mathrm{msec}$, a positive response to pacemaker stimulation was not obtained. The result in accordance

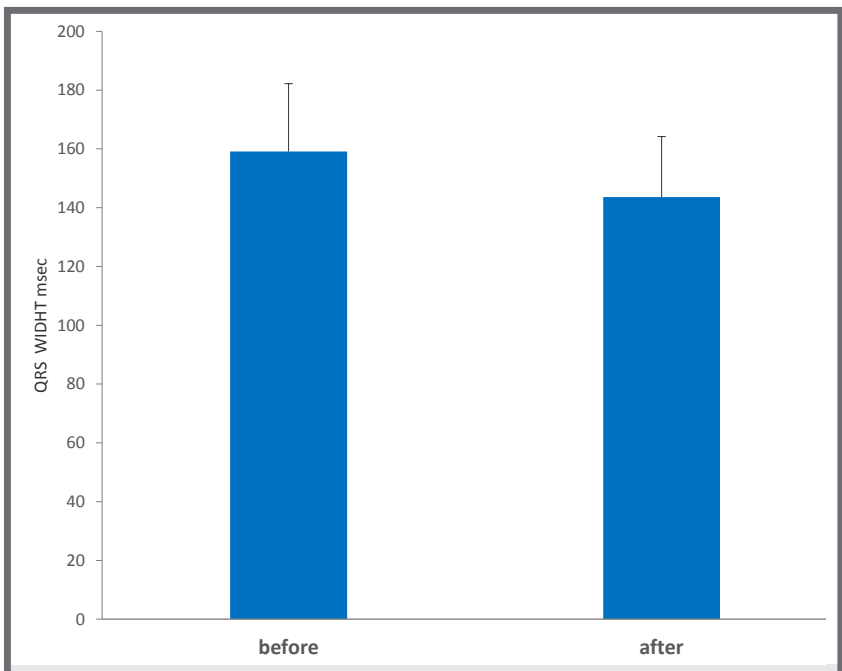

Figure 2. QRS width before and after treatment

with the ESC recommendationthat benefits from CRT stimulation is not expected in RBBB.

- Improved in NYHA HF class

The highest number of respondents after the intervention was in functional NYHA class II 51 (48.6\%), and prior to intervention in NYHA III class 62 (59\%), with a statistically significant difference in the NYHA class before and after intervention $(Z=-7.587 ; p<0.001)$. After a year of stimulation, $30.5 \%$ of the subjects were in the functional NYHA class I, and non in the functional NYHA class IV.

Table 1. NYHA class before and after treatment

\begin{tabular}{|c|c|c|c|c|}
\hline \multirow{2}{*}{ NYHA CLASS } & \multicolumn{2}{|c|}{ NYHA } & \multicolumn{2}{c|}{ NYHA } \\
\cline { 2 - 6 } & \multicolumn{2}{|c|}{ Before } & \multicolumn{2}{c|}{ After } \\
\hline I & $n$ & $\%$ & $n$ & $\%$ \\
\hline II & 0 & 0,0 & 32 & 30,5 \\
\hline III & 62 & 40,0 & 51 & 48,6 \\
\hline IV & 1 & 1,0 & 0 & 0,0 \\
\hline
\end{tabular}

- Increased distance passed in 6MHWT.

The distance traveled over a 6-minute walk in a corridor on a flat surface was $358.1+124.5 \mathrm{~m}$ after the intervention, which is a statistically significant difference from $154.3+82.6 \mathrm{~m}$ preimplantation distance $(\mathrm{t}=$ 11.320; $p<0.001)$.

- Global systolic functions of the left ventricle have been improved.

EFLV increased on average by $10.9 \%$ and after intervention it was $36.9 \pm 10.9 \%$, which was statistically significant improvement compared to baseline EFLV, which was $26.0 \pm 5.9 \%$ ( $t=10.477 ; p<0.001)$.

Among the 105 patients covered by the analysis, $60 \%$ were responders, $15 \%$ were super responders and $25 \%$ were non-responders to CRT. 


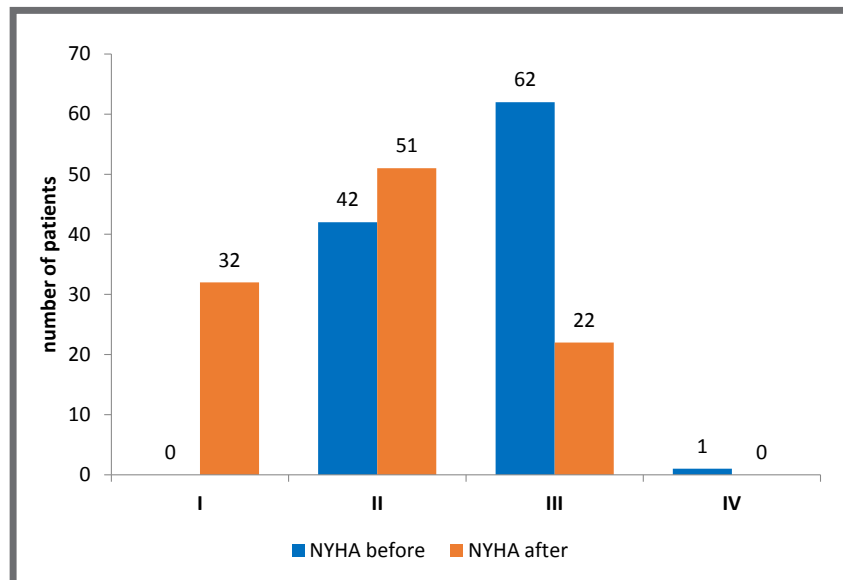

Figure 3. NYHA class before and after CRT implantation

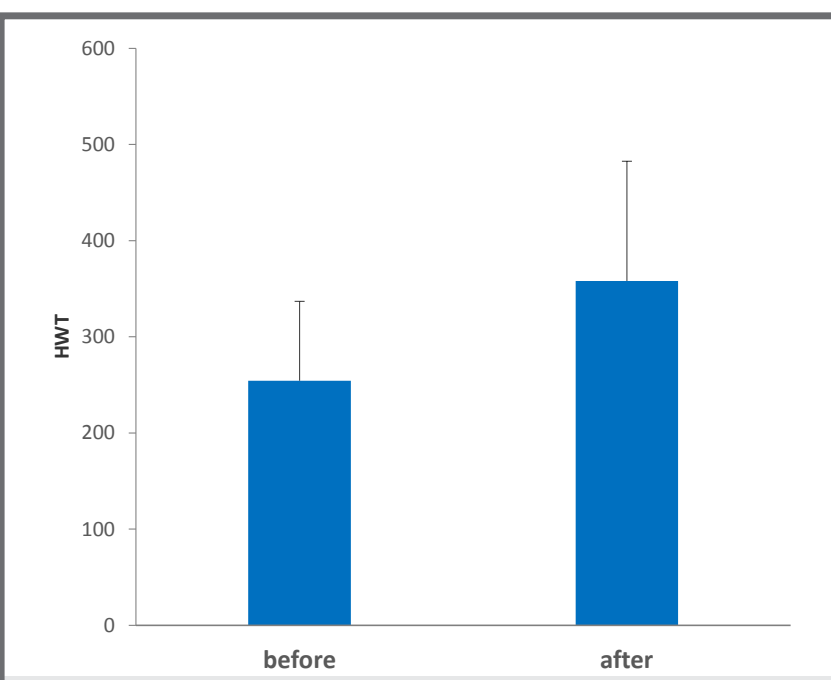

Figure 5. 6 minutes walking test before and after CRT

- A statistically significant difference in the number of hospitalizations before and after intervention. Prior to interventions, the respondents most often had 1 hospitalization (35.2\%), while after the intervention, they were most often without hospitalization (62.9\%). There is a statistically significant difference in the number of hospitalizations before and after intervention $(Z=-6.847 ; p$ $<0.001$ ).

- Reduction in the frequency of diuretic administration after implantation of CRT were recording in $62.4 \%$.

- The death in the observed period was observed in 4 patients, or $5 \%$ of the examined group.

\section{Discussion}

By analyzing baseline data for 105 patients included in this study, all of them had symptomatic systolic HF despite optimal medication therapy involving Beta blockers, ACE inhibitors or ARB, MRA. A large number of subjects daily used diuretics, more times during the year prior to the implementation of the CRT was hospitalized. The majority of the patients were in the functional NYHA class II and III, and one respondent in the functional NYHA class IV. The implementation of CRT in patients with moderate HF in the NYHA I-II class, which was carried out in several of our respondents, confirms the results of several ran-

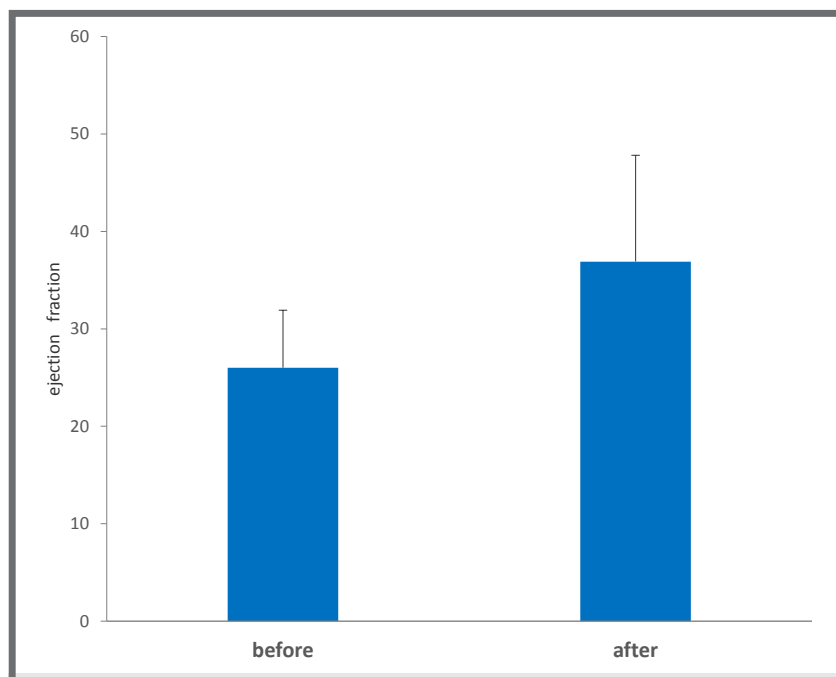

Figure 4. Improvement in LVEF

domized studies that the CRT should not be delayed, but started earlier, until there was a pronounced change in the LV geometry. If the expected survival time for patients is over a year, if they are in the sinus rhythm with a QRS complex of $>150$ ms width in LBBB, and EFLV $<35 \%$, regardless of the symptoms, CRT, treatment is indicated also in these patients.

Although all of our respondents had an ECHO proven chamber asynchrony, the percentage of non-responders confirms the results of the first PROSPECT study, that echocardiography is unable to identify a reliable and safe predictive marker for the response to the CRT. However, echocardiography is now inevitable in assessing the mechanical asynchrony and optimization of $A-V$ and $V-V$ times.

The duration of the QRS complex remains the most practical and most valid parameter for patient selection, since its predictive value stems from a strong correlation with mechanical asynchronization, which is again emphasized in the ESC recommendations. All of our respondents (except one) had QRS duration $>120 \mathrm{msec}$, LBBB morphology, except for two patients who had RBBB. Both respondents with RBBB were CRT responders, which confirms the fact that patients with RBBB can benefit from the use of this method, although , according to the ESC guidelines, in patients with QRS morphology by type.

RBBB, it is generally not expected benefit from CRT. The decision on the use of CRT should be individualized on these patients based on other clinical and image criteria. A QRS width of $160 \mathrm{msec}$ in one patient with a right branch block, and a positive response to the CRT, confirms the fact that the QRS morphology of RBBB, 150 ms wide, also covers LBBB In our group, left ventricular stimulation was realized by endovenous positioning (except for two surgical seizures) of epicardial electrodes via the lateral and posterolateral CS veins on the basal or middle part of the lateral LV wall, which in all CRT studies were the optimal sites of canulation and stimulation. In all patients in our analysis, apical place of LV stimulation was avoided, which is in line with the results of the MADIT-CRT study on the harmfulness of LV 
stimulation from the apex region, primarily due to a small interelectrode distance and poor resynchronization, which can result in deterioration of the LV symmetry, and even fatal outcome. It should be noted that the optimal hemodynamic response to the CRT depends not only on the site of stimulation of LV, but also on the optimization of $\mathrm{A}-\mathrm{V}$ and $\mathrm{V}-\mathrm{V}$ intervals ${ }^{3}$ Some of the latest studies indicate positive effects of CRT and in the nonambulatory NYHA IV class, but more confirmation studies are needed. ${ }^{4}$ The positioning of the electrode for $\mathrm{LV}$ as well as the number of electrodes is still often a compromise between theoretical, optimal pacing, and technical possibilities, with the suggestion of many authors that the optimal position and number of electrodes for stimulating the LK can be different from patients to patients. $^{5}$

\section{Conclusion}

Over the past more than two decades, CRT has evolved from concept to clinical application. Due to CRT clinical application, mortality has been reduced, clinical condition improved, as well as quality of life. A small positive change in the quality of life of these patients is further impetus for the improvement of this method.
Some of the latest studies indicate positive effects of CRT in NYHA IV heart failure functional class, but more studies are needed to confirm these results. Finally, CRT has shown significant symptomatic improvements as well as a strong positive effect on slowing progression of the disease.

Učitelju i mentoru Prof dr Goranu Milašinoviću, od koga sam naučio da kraj puta ne postoji, već da je završetak prethodnog samo početak novog. Beskrajni plavi krug. U njemu zvezda.

\section{References}

1. Sefereovic PM, et al. Nacionalni vodič dobre kliničke prakse za dijagnostikovanje i lečenje srčane insuficijencije 2012.

2. Aurrichio A, et al. Cardiac resynchronization therapy. J Am Coll Cardiol 2008;51:1463-1465.

3. Milašinović G. Dodatna elektroda za stimulaciju LK kod bolesnika sa implantiranim resinhronizacionim pejsmejkerima i defibrilatorima Rad uže specijalizacije, 2010:7-12.

4. Yamashita $S$, et al. The effectiveness of cardiac resynchronization therapy for patients with New York Heart Association class IV non-ambulatory heart failure. J Arrhythmia 2015;314:221-225.

5. Alonso $C$. In the field of cardiac resynchronization therapy is left ventricular pacing via the coronary sinus a mature technique. Europace 2009;11: 544-545. 


\section{Sažetak}

\section{Rezultati lečenja srčane slabosti resinhronizacionom pejsmejker terapijom}

Ž.Delići ${ }^{1}$ S.Ćirković ${ }^{2}$

${ }^{1}$ Opšta bolnica Vrbas, ${ }^{2}$ Opšta bolnica Požarevac

Uvod: Resinhronizaciona terapija sistolne srčane slabosti , (CRT), poboljšava simptome sistolne srčane slabosti, funkcionalnu sposobnost $i$ kvalitet života, smanjuje smrtnost i produžava očekivani životni vek.

Cilj: Cilj ove studije bilo je praćenje rezultata lečenja sistolne srčane slabosti, pomoću CRT-a, najmanje 12 meseci posle implantacije.

Metode: Analiza je bila retrospektivna i prikazuje efekte terapije CRT om kod 105 pacijenata (77 muškaraca), srednje starosti $63 \pm 8,7$, godina, širine QRS kompleksa 159,1 $\pm 23,1 \mathrm{msec}$, NYHA klase II, III i ambulatorne klase IV, sa optimalnom medikamentoznom terapijom. 36 ispitanika je imalo srčanu slabost kao posledicu ishemijske kardiomiopatije / prethodni infarkt je imalo 25 pacijenata (23,8\%), a 69 ispitanika sistolnu srčanu slabost neishemijske geneze. Retrospektivnom analizom ostvarenom uvidom u istorije bolesti, kartone kontrolnih pregleda i EHO bazu Pejsmejker centra KCS u Beogradu, te podatke dobijene u telefonskom kontaktu sa ispitanicima, poređeni su rezultati efikasnosti ove terapije . Kao parametre pozitivnog kliničkog odgovora na CRT uzeli smo:

- Smanjenje NYHA klase srčane slabosti za 1 klasu ili više • Povećanje pređene distance u 6/minutnom testu hodanja po ravnom za više od $20 \%$

- Smanjenje doze diuretika u terapiji

- Smanjenjen broja hospitalizacija

- Porast EFLK za više od $5 \%$

Rezultati: 12 meseci posle implantacije CRT-a, postojalo je statistički značajno smanjene širine QRS kompleksa, NYHA funkcionalne klase, kao i produženje pređene distance u šestominutnom testu hoda po ravnom 6MHWT, poboljšanje ejekcione frakcje leve komore (LVEF\%.) Postignuta je statistički značajna razlika u broju hospitalizacija pre i posle intervencije, značajno smanjena potreba za uzimanjem diuretika. 60\% pacijenata je odgovorilo na CRT, $15 \%$ pripada grupi super-respondera, a $25 \%$ su bili neresponderi na CRT.

Zaključak: Zahvaljujući primeni CRT-a, poboljšan je klinički status, smanjena je smrtnost, poboljšan kvalitet života bolesnika sa simptomatskom sistolnom srčanom slabošću.

Ključne reči: srčana slabost, resinhronizaciona pejsmejker terapija 